\title{
Translating 'shame'. A translational approach (I)
}

\author{
Magda Jeanrenaud* \\ Faculty of Letters, "Alexandru Ioan Cuza" University, Bd. Carol I 11, 700506 Iaşi, Romania
}

\section{Article info}

History:

Received December 11, 2016

Accepted January 9, 2017

Published March 23, 2017

Key words:

translation

semantics of 'shame'

translation of concepts

neologization

specialized translation

\begin{abstract}
Starting from the semantic and lexical sphere of the concepts of 'honte' (in French) and 'rușine' (in Romanian), my aim is to examine the way this word was translated into Romanian; for this purpose, my point of departure was a case study. To this end, I tried to elaborate a comparative translational study of Boris Cyrulnik, titled Mourir de dire. La honte (Éditions Odile Jacob, Paris, 2010) and of its Romanian translation, titled Mai bine mor decît să spun. Ruşinea (French translation by Valentin Protopopescu, Editura Trei, "Psihologia pentru toți" collection, Bucharest, 2012). Cyrulnik's text has a particularity: it oscillates between the specifics of a literary text and those of a specialized text. From this standpoint, his transposition challenges the functionalist theories of translation and mostly the skopos theory elaborated by Katharina Reiss and Hans Vermeer: it is interesting to analyse the way the translator "decodes" the "intentionality" of this type of text, ultimately a specialized text, and the way he decides to transpose its semantic and lexical sphere into Romanian.
\end{abstract}

\section{By way of introduction}

The first Romanian translators of early $19^{\text {th }}$ century lacked the language instinct, which may be explained by both the absence of predecessors and the fact that Romanian literary language itself was still settling. Of course, such phenomenon occurs in all cultures when the language undergoes a normative process. Towards the end of the century, according to Pompiliu Eliade and others, the language vocabulary had developed enough resources "concerning concrete and current use matters," but "to express abstract ideas, it was sometimes necessary to borrow terms from French" (Eliade, 2000, p. 291). Other scholars had pointed out these lacks previously: Ion Heliade-Rădulescu, for instance, had already noted that Romanian was particularly rigid concerning "the translation of philosophically rich works" (Popovici, 1977, p. 156). This determined him to elaborate an educational and normative vocabulary of neologisms that would include an entire array of terms that he considered necessary for the language, "mostly in sciences," in his opinion (Popovici, 1977, p. 178). Many regarded the lack of an adequate inventory of notional terms as a default of the Romanian language in that period. The phenomenon was also confirmed by Paul Cornea, who unravelled the scarcity of terminologies necessary to translate scientific works (Cornea, 1972, p. 97).

It appears that it was not a short-lived phenomenon; it continued in the interwar period, too. Moreover, according to certain opinions, it lived longer and even underwent some sort of "institutionalization" process. Some voices explained it by the fragmentation of a society suffering from intense polarization, due to the inexistence of a clearly configured middle class. This is anyway the suggestion of D. Popovici, who wondered how we could explain such a significant social fragmentation during the time of Ion HeliadeRădulescu. He also tried to explain the lack of interest manifested for his universal library project, which should have stimulated an extensive and systematic activity of translation. However, as he pointed out, the indifference displayed for this program would have been explained by the fact that "many of those who could have supported Heliade's efforts actually had no need for translations, for they were able to address directly to the original" (Popovici, 1977, p. 205). Other voices pinpointed-on a more dramatic

*Email address: mjeanrenaud@hotmail.com. 
Magda Jeanrenaud

note-that the configuration of the Romanian society would have represented "Romanian's bad luck in the interwar period," insofar as, while the "Romanian cultural elite guarded with much pride their elitist culture," the "popular" reader could only access an "industrial literature" through translations (CleynenSerghiev, 2003, p. 71) ${ }^{1}$. By drawing a parallel to the well-known scheme of Robert Escarpit, I state that the "cultured circuit" within the Romanian space was configured exclusively by the "distribution of French works in the language of origin," while the demand of translations was limited to the "popular circuit" (Cleynen-Serghiev, 2003, p. 54).

Let us make another leap over time: we notice that the lack of coherence of a well-structured notional lexicon was still invoked in late twentieth century. Whereas, in the 1970s and 1980s, the projects of great publishing houses such as Meridiane, Univers or Minerva had launched successfully their "most spectacular action [...], of translating literary and aesthetic exegesis," ${ }^{2}$, Gelu Ionescu still highlighted a "very current and stringent need" (Ionescu, 1981, p. 33) of enriching and refining the notional lexicon.

This is the reason why I decided to study today, at the beginning of the twenty-first century, the conduct of translators. They play a significant role in the transposing specialized terminologies, concepts and their structuring into the Romanian language. To this end, my goal was to examine the translation of the concept of rusine [shame] and of the derived vocabulary, in order to study the translator's approach to the specialized terms within a scientific work that includes it in the very title. It is the book penned by the renowned French psychiatrist and psychoanalyst Boris Cyrulnik, who introduced the concept of resilience in France. This book is titled Mourir de dire. La Honte [Telling and Dying of Shame], published in 2010 in Paris, by the publishing house Odile Jacob. The Romanian version-signed by Valentin Protopopescu - was published shortly afterwards, in 2012, by the publishing house Trei, which specializes in the publication of works in the fields of psychology, psychoanalysis, psychotherapy, etc.

The book is a discourse on shame viewed as a manifestation of a significant trauma, a serious condition that the therapist, psychologist, psychiatrist or psychoanalyst who writes this discourse strives to cure. From the very beginning however, the discourse on shame proves difficult to articulate, insofar as shame is not told; silence is, in fact, a component of this trauma. Hence, the role of the therapist-in our case, of the narrator-is to determine it to be expressed in words. Furthermore, our narrator is not a distanced subject, who assumes mainly a scientific discourse, but he sometimes transforms, in his turn, into a subject affected by this trauma. This is a discourse on shame assumed by a subject who speaks on behalf of those ashamed because they are not able to speak: shame refuses to allow to be uttered. For this type of text, the transposition into translation of the semantic field pertaining to the core notion of shame should not be problematic per se. There is no risk of disseminating the meanings of the concept in question into polysemous and isotopic networks, because it has a double delimitation: at micro-textual level (related to context) and at macro-textual level (precisely by the type of the text).

The text appears as a sort of coming-and-going: the specialist in neuropsychiatry talks ${ }^{3}$ about the shame of others; upon discussing his own shame, he fails to assume it using the first person and he shifts the discourse towards the third person. A theoretician of resilience, of methods used to overcome a trauma in the reconstruction of personality, the author concludes that three factors prevent this process. The first two-physical isolation and enclosure in verbal nonsense-act together and they may be overcome only using words. The one who experienced the trauma must make the effort of constructing the story of his trauma, which is the only way of providing coherence, of attributing an order and a meaning to the events. On the contrary, the third factor-shame-blocks the other two, thus preventing the construction of the story: shame forms a symmetrical pair with silence (Cyrulnik, 2013).

Thus, shame appears to be an individual trauma, but which acquires a shape from the standpoint

\footnotetext{
${ }^{1}$ I take full responsibility for the translation of all French citations.

${ }^{2}$ Cleynen-Serghiev (2003, p. 54). The Heliade project "is still of actuality - in the sense that it has not been fully completed," p. 31, p. 49.

${ }^{3}$ See also the radio show titled "Le thêâtre intime de la honte" [The Intimate Theatre of Shame], France Culture, Sept. 30, 2015.
} 
of the others. More than impudence (more closely related to the function of ego in society; it involves less directly the refusal/incapability of uttering), shame remains intimately related to the development of personality, to the ego's capacity of Thus, shame appears to be an individual trauma, but which acquires a shape from the standpoint of the others. More than impudence (more closely related to the function of ego in society; it involves less directly the refusal/incapability of uttering), shame remains intimately related to the development of personality, to the ego's capacity of perceiving the others and to the way the others perceive the ego. Indeed, this feeling, this emotion "translates our aptitude of perceiving the mental world of the other," in other words of "perceiving mentally the existence of the other" (Cyrulnik, 2010b).

Hence, the text has a multi-layer structure: a psychological and psychoanalytical study of a disorder; an attempt of popularizing a difficult topic; but also a paradoxical text of the untold, because shame is marked by the impossibility of telling it (except for the different skin tone) by those traumatized. "La honte ne peut pas se dire" (p. 38), concludes the author using the neutral tone of a practitioner. However, the Romanian version chooses "rușinea nu poate fi mărturisită" (p. 36): a terrible misinterpretation, because the issue of the person in pain is the telling, the uttering, the capability of expressing the pain in a distanced manner, as such, as a first step towards healing, according to the French text. It is not about confessing it, like a blame (taken upon oneself). Perhaps a mărturisi [to confess] "sounds" better. It may be more poetic than the common a spune [to tell], but by choosing it the translator concomitantly half-opens the door for betrayal: a clinician's aim is not to express using a diverse but poetizing vocabulary, but to do his jobs using specific terms. Moreover, the sentence makes a direct reference to the title itself, which the Romanian version fails to do, having shifted to the level of confessing.

\section{What kind of text: the translation perspective}

The first thing a translator must do is to ask himself what kind of text he is about to translate, in order to decide its textual genre and to include it subsequently within a typology. However, such inclusions have no relevance if they are made without relating to a typology of texts to translate. Such typology should not take into account the classifications of literary tradition, but it should operate by hierarchies that are strictly related to translating manners. Quite recently, the translation theories and their critique and evaluation have started paying increasing attention to the type of text to translate and to the intentionality expressed by the text. The two are determining elements in the decision-making process regarding the translation techniques. One of the most flexible functionalist theories of translation-which also played a considerable role in the détente of the fidelity / betrayal binomial in the act of translation-is the socalled skopos theory. It may not be coincidental that it was elaborated in the German space, if we take into account that in the German culture the association of translation with betrayal was more sporadic than in Romanic languages and cultures. Through the translation of the Bible by Martin Luther, the semantic sphere of the translation concept revolved more around the idea of transmission, transplantation, and less around the idea of fidelity.

Though different, the opinions on the specificity of philosophical text (and, more generally, on the discourse of humanities in terms of requiring distinct translation techniques and decisions) agree on one aspect. Namely, they all believe it is necessary to surpass the traditional binarism dividing the texts to translate into two categories: pragmatic texts and literary texts. This dichotomy has always valued literary translation to the detriment of specialized translation. The latter has been viewed more like a rigid mechanism of transposing certain terminological inventories from one language into another. Drawing on Karl Bühler's scheme and on Jakobson's concept of dominant, Katharina Reiss (2002, p. 30-60) has elaborated a very flexible typology focusing on the predominance of one function or another of language, which differentiates three categories of texts to translate. Operative texts, where the appellative function is dominant, must be translated taking into account the intense presence of the aforementioned function. Hence, they should be translated by their intentionality, by using an entire array of procedures capable 
of producing an extra-linguistic effect on the recipient, thus stirring a predetermined reaction. Expressive texts, which rely heavily on the expressive function of language, should be transposed from the perspective of their form, because their specificity derives from the use of stylistic, aesthetic, semantic and grammatical procedures. Finally, informative texts can be assigned to the representational function of language: the translator must consider it first and he must focus on adequately conveying the content; thus, the formal configuration is somewhat of a lesser importance. The so-called specialized texts are included in the category of informative text types because their main purpose is to pass on the content, which the translator must reproduce integrally, by aiming to obtain the invariance of content (Reiss, 2002, p. 56). It becomes clear that such typology focusing on the criterion of dominant function of the text to translate also tends to manage the tensions related to the dramatic certainty of theory and of many translators regarding the inevitable losses occurring in all translation processes. Such losses occur when this process is viewed as a path aiming to reproduce integrally the original. Hence, at least theoretically, we consolidate the possibility of limiting the "losses" or at least of considering them secondary, acceptable, insofar as the goal of the translation becomes the production of an equivalent target-language text (the famous equivalence without identity coined by Paul Ricœur) (Ricœur, 2005, p. 90), where success is closely connected to reconstructing the dominant function of the source text. The transposition of the dominant function of the source text, in other words of its skopos-correctly deciphered by the translator in order to apply the right translational strategies has two consequences. On one hand, the text consolidated the recipient's position; on the other, it shifts to the secondary plane the fidelity / betrayal binomial. From this perspective, fidelity no longer associates the two texts pursuant to a direct filiation, while betrayal is diluted, insofar as it even acquires legitimacy and it is taken over by a sum of translational techniques that do not require their absolute conformity anymore.

The work under analysis in this paper can be included without hesitation in the category that Reiss calls texts with informative dominant (Reiss, 2002, p. 44), along with theses, essays, monographs, didactic works, treatises, reports, press comments-in a word, texts pertaining to humanities. Their common element in terms of translation strategies is the dominant, namely the conveying of content. However, one should avoid falling in the trap of a purely functionalist view of language, thus omitting that " $h o w$ a thought is expressed is hardly less important than what is expressed" (p. 45). However, the manner in which a translator uses one expressive means or another is subordinated, in this case, to the conveying of content. The translator will produce a satisfactory translation only insofar as he finds the right way of fully transposing the cognitive content, in other words the topic and its discussion (p. 46), its "semantic, grammatical and stylistic" characteristics (p. 45).

Besides the presence of specialized terminology — with variable proportions depending on the genre-, informative texts for popularization or of an essayist nature, with literary ambitions, should be characterized by "material accuracy, precise information and current language" (Reiss 2002, 47). Boris Cyrulnik's book addresses a lay public of broader interests, reason for which the translation "show show greater attention to stylistic matters" (Reiss, 2002, p. 47). Indeed, "once a text is identified as belonging to the content-focused type, an important component of its translation method has been determined" (p. 47). The translator must focus on obtaining "invariance in transfer of [...] content" by using not only a correct, but also a current language (p. 48), all the more as the text in question is developed on a double-layer structure. Namely, one can distinguish between the narration (as the product of a narrator taking the responsibility of a character) and the impersonal argumentation of a theoretical topic.

\section{The title and its translations}

Starting from these elements, I can analyse the way the title was translated and then the way the networks making up the lexical field of shame in this text were transposed. The book has been translated into German, Spanish and Romanian. The improbable relationship between a discourse-essentially a telling of something: shame - that also essentially refuses the telling is also reflected in the various decisions made 
with regard to the translation of the title. The original title-Mourir de dire. La honte-is probably inspired by a study penned by the psychoanalyst Rachel Rosenblum. However, her title was interrogative (“Peut-on mourir de dire?") (Rosenblum, 2000, apud Cyrulnik, 2010a. Cf. Rosenblum, 2000, p. 113138), which the author clarified at the beginning of her abstract, also by means of a question: "Peut-on mourir d'écrire la catastrophe?" The great catastrophes, she states, have something in common: the untold, an untold that may lead to definitive silence, to death. However, the author then asks, writing, telling, revealing a trauma is not a "decision with serious consequences," too? Can one die because of telling? Great writers such as Sarah Kofman or Primo Levi provided an answer to this question. An answer, an even more dramatic one, was also given by Paul Celan, who had always found "the right words, even in the language of the assassins" (Rosenblum, 2000, p. 115). Furthermore, as Jorge Semprun formulates irrevocably, there are times when a choice has to be made: to live or to write (Semprun, 1994).

I have made this digression in order to suggest that one should not treat lightly the difficulty of translating a title that associates the verbs a spune [to tell] and a muri [to die] with shame. The French title comprises two infinitives, namely-according to Larousse- "nominal forms whose essential function is to simply enounce the process expressed by the verb." Thus, they are impersonal and timeless; they are abstractions that express the idea of an action or of a state. From this standpoint, the Romanian version, Mai bine mor decit să spun, beyond its playful, lively tone that pushes this formula in a very different register than the text following it, also opens the gates of a terrible misinterpretation. In the Romanian version, the subject proclaims in a personal, vivacious and seemingly joyful manner (i.e. it is similar to the sonorities of children's play songs: six short words, alternating one-syllable and two-syllable words) the capacity of keeping a secret. Hence, the subject expresses the will of not telling using a comparative phrasing. Moreover, the association with the second part-shame - thus reads like a promise, like a commitment to keep silent, the transgression of which could bring along death. It is not quite the same as the semantics of the original title; the translator chooses a construction meant to draw attention, like so many others that use of language that we may call media-specific. The comparative clause of inequality mai bine... decit [rather... than] or decit... mai bine [than... rather] expresses an opposition through a comparison (Graur, 1973; Craşoveanu, 2002, p. 65-66): it compares two contradictory facts, which is far from the intention of the original text. It also renders the reference opaque and it contrasts with the term ruşine [shame], which completes the first segment in the French original, thus singularizing and clarifying the impersonal stance expressed by it. Hence, shame becomes some sort of punishment for telling, which contradicts the entire content of the book, following the title Mai bine mor decît să spun. Ruşinea.

In German, the title was transposed as Scham. Im Bann des Schweigens - Wenn die Seele vergiftet (Cyrulnik, 2011a), which forces massively the explicitation of the key-term shame placed at the end in the original title, in order to render the generality of "mourir de dire." The lexical field of shame-which highlights silence-extends and it becomes a "poison of the soul." Indeed, this is a recurrent formula in the original book; the German version actually delimited from the very beginning the essential features of the notion of shame by reversing the general-particular direction of the original title.

In Spanish, the title was translated as Morirse de vergüenza. El miedo a la mirada del otro (Cyrulnik, 2011b) (the fear of the other's look). The Spanish title also particularizes the theme of shame, but the method of choice is a paroxysmal idiom, "to die of shame," which it determines using a subtitle explicitating it. The translation is rather different from the original, because it no longer references the impact of silence that destroys the ego and it places the origin of the trauma not in the untold, but in the look of the other.

The Spanish term vergüenza has had a different evolution than the French vergogne, considered today an archaizing and literary term; it is still used only in the phrase sans vergogne [shamelessly]. Always associated with a "marker of negativity," the term ended up suggesting "a kindly disapproval similar to irony." The subject thus characterized shows especially a "lack of scruples and reserve" (Cassin, 2004, p. 1338), to which an "immoral connotation" may be ascribed. In Spanish, however, "the reason for shame [...] is related to perjury, to the violation of a commitment that alters dignity" (un hombre con vergüenza). Consequently, it affects the relationship with the social, with the collective, which represents the core of 
its semantic sphere. In both Italian and Spanish, the term is closely related to self-esteem and to a collective feeling (vergüenza ajena, literally shame caused by the behavior of others; in French, la vergogne de l'autre) (Cassin, 2004, p. 1339). Therefore, its total absence from the French version demonstrates that it is not connected in any way to the specialized psychological language of the book. This stands to confirm the dominant of this type of text and it represents yet another sign for any vigilant translator, who should aim in his translation the "invariance of content," thus resisting to poetizing temptations.

As for a potential title in English (to my knowledge, there is still no English translation of the book), the English version of the Odile Jacob website features the book as Telling and Dying of Shame. My opinion is that this phrasing, which coordinates in a single structure the telling and the sanction for not telling, is the closest to the original title.

\section{Title coherence: its role in the construction of the main text isotopy}

It is common for the title to be reprised in the text, and this repetitive reflection has-besides a "didactic" function - the purpose of ensuring the coherence of the text as a whole. Such redundancies are never coincidental, but they help consolidating the textual framework; they create and supply the networks of meaning and often the very symbolism of a text.

We are provided with an explanation of the title and even with a reference to the paper signed by Rachel Rosenblum in the second page of the Romanian version: "Il croit qu'il va mourir de dire" (p. 8), in the author's words. The Romanian translator prefers "El este încredințat că va muri dacă nu o să vorbească" (p. 8), while the Spanish one, for instance, reprises the segment within the title: "Cree que se morirá de vergüenza." The same segment is reprised in the original text, referencing again the text written by Rachel Rosenblum (p. 84), in order to underscore the complex interaction between two stories: the one of the ego about the self and the one that the others construct about the self. The latter can sometimes destabilize the ego, thus deepening the wounds: "Dans une telle enveloppe verbale, on peut très bien «mourir de dire» et souffrir de ne pas dire." In Romanian, though, it reads "Într-un asemenea înveliș verbal se poate foarte uşor «muri pentru o vorbă» și suferi pentru că nu am spus-o” (p. 78). Comprehension is perturbed not only by the passage from the impersonal to the personal mood, but also by having destroyed the coherence of the title. I also have to mention, yet again, the poetizing frivolity of "a muri pentru o vorbă," which fails to express trauma and the capability of telling it.

\section{On the semantics of shame}

Undoubtedly, shame - which paralyzes, in case of deep traumas (but not exclusively) the capacity of transposing them into words-is difficult to translate. I have already shown all the precaution measures taken by translators concerning the title: the German version in particular used excessive explicitation of the semantic field of shame. The fact has a twofold explanation: one related to the evolution of the term in the usual lexicon of the German language, and another one related to the particularities of elaborating its specialized significance within psychoanalysis and mainly within the Freudian lexicon.

Claude Janin (2003) wrote an ample study dedicated to "the psychoanalytical theory of shame," where he starts from the differentiation of two levels of sense within the concept of shame: the first refers to the sphere of privacy (related to shame per se), while the other refers to the social sphere, namely to pudoare. The same Janin (2003) cited - in a section dedicated to the semantics of shame and to its translation into English and French in case of Gesammelte Werke by Freud-the opinions uttered by Warren Kinston (Kinston, 1983, apud Janin, 2003, p. 1659) ${ }^{4}$. According to the latter, the two levels are less differentiated in English, which uses the same term for rusine and pudoare (shame), while French and German (I would add Romanian) benefit from two terms.

\footnotetext{
${ }^{4}$ Furthermore, Kinston determined the equivalence between Scham and pudoare but also between Schande and ruşine,
} based on the German derivative Blutschande for incest. 
The distinctions operated by both the famous French glossary (Bourguignon et al., 1989, apud Janin, 2003) elaborated for translating the complete works of Freud and the correspondence tables of the English Standard Edition and by the translators between the equivalences of Scham and Schande are hesitant. ${ }^{5}$ This stands to highlight again the variation of the semantic fields from German to English. The French authors believe that Schande corresponds to pudoare, but that it may also mean rusine; however, all of them show that both terms intersect sometimes, insofar as the intimate, the sexuality and the social are difficult to separate. The occurrences of the term Schande in Micul Hans, for instance, were translated into Romanian by ruşine (Freud, 2010b, p. 11-141; Freud, 1909), which consolidates the idea of a mixture between the intimate and the social sphere for the two terms. When Schande referred to contexts with sexual connotations, it was transposed constantly by ruşine / honte (Freud, 2010a) ${ }^{6}$, while in Traumdeutung, for instance, which - to my knowledge-includes one occurrence of Schande (in chapter five) related to sexuality, it was translated by the same rusine.

Hence, Scham is associated with pudoare considering the connection with the anatomic sphere and with the pain caused by the revealing of something that should have remained a secret. Janin compares diverse dictionary definitions of the French term honte, which shows that the distinction between intimate and social, between the mental and the social character of shame is not as obvious as in German; it also shows the impossibility of demarcating clearly between ruşine and pudoare. On the other hand, Janin states, the lack of a theory of shame in Freud's work had consequences on the subsequent theoretical evolutions but also, in my opinion, on the translation of the lexicon for shame. Maybe we can thus explain the considerable amplification of the German title, where Scham (the pivotal word of the title) benefits from a double determination: Im Bann des Schweigens - Wenn die Seele vergiftet.

In most French and Romanian dictionaries, rusinea [la honte] and pudoarea [la pudeur] are considered synonymous. The website of the Centre National des Ressources Textuelles et Lexicales lists 46 synonyms for bonte, while pudeur ranks the fifth in terms of frequency. Out of the eight featured antonyms, all with the same frequency, impudeur ranks the sixth. Among the synonyms of pudeur, honte ranks the sixth, significantly less frequent than, for instance, retenue, réserve, décence. The Romanian DEX associates the following meanings to ruşine: 1 . Shyness, abashment caused by a failure or a mistake; 2 . Reserve, modesty, shyness; 3. Offense; 4. Dishonor, humiliation, belittling; 5. Name of genital organs. Pudoare is defined as follows: 1. Shyness, abashment, decency and, in juridical language, referring to sexuality, in the phrase atentat la pudoare.

Therefore, in a specialized text with a psychological and psychoanalytical topic, la honte must be rendered as concretely as possible by rușine, namely the term capable of expressing a trauma, not by pudoare, which denotes a shy, discrete and reserved type of shame. In Romanian, the noun ruşine does not have an antonym based on the prefix ne- or im-, while pudoare has the antonym impudoare. In French, (the language of origin for the Romanian pudoare), la honte (shame) lists among its antonyms precisely the term... impudeur. It is quite probable for the very etymology of rusine-related to the Latin roseus, which directly references the red colour-to determine a closer connection with the perceptible in case of the Romanian term. The physiological, palpable manifestation of shame is the red colouring of cheeks for the entire human species, but in the Romanian language, this aspect is thus included, encompassed in its semantic sphere. However, it is also necessary for its lexicon and its surrounding lexical field to preserve in a translation the coherence of the key-term.

\section{Shame can be quantified}

Unlike pudoare, rusine is thus "measurable"; it has a "quantity" in an almost literal sense of the word: precisely because ruşinea references in both French and Romanian something concrete, a subchapter is

\footnotetext{
590 occurrences of shame correspond to the 42 of the German text (Janin, 2003, p. 1658).

${ }^{6}$ Especially chapter five, Materialul și sursele visului (cf. Freud, 1900, cap. V, Das Traummaterial und die Traumquellen („Pfui, das ist eine Schande, das darf man nicht” [Pfui, e rușine, nu e voie]).
} 
titled Peut-on chiffrer la honte? (p. 91-94) // Putem să cuantificăm ruşinea? (p. 83-86): ruşinea can be "quantified," to a much greater extent than pudoarea, as proven by the morphosyntactic functioning of the two terms. Ruşinea can be small or big; it can be heavy by its weight or it can be uşoară [light] (we say industrie uşoară [light industry], but also boală uşoară [mild disease], just like moravuri [morals] can be ussoare [promiscuous], right?). However, the translator varies more than suggested in the original text (in this case, variation connotes hesitation): furthermore, he prefers terms with polysemous potential, which undermines implicitly the denotative path. Thus, la petite honte becomes mărunta rușine, or o uşoară senzație de rușine, or un uşor sentiment de ruşine, while grande honte becomes marea rușine, but also o rușine amplificată. As for le moindre sentiment de honte, where moindre refers to an abstract but most times quantifiable notion, it is translated by mărunt, which does not accept quantification and whose figurative meaning diminishes the clarity of the original text.

At the very beginning of the book, it reads-in the subchapter titled Transparence du honteux (Transparența celui care suferă de rușine) - that la honte lui tombe en pleine tête (p. 33), and the translator chooses to render the full physical range of the phrase by using rusinea îl izbește frontal (p. 32). However, the intralinguistic instructions of the source text were clear and they simply had to be followed consistently throughout the text. In French, la honte bears in a very concrete sense a weight, un poids, which is again diluted (even mistranslated) in apăsare a ruşinii, because it turns a property into a sensation of an object, which can be apăsat [burdened] by shame. A similar situation can be highlighted for the structure la honte est plus légère (p. 26), translated by rușinea este mai suportabilă (p. 24), where again an outside instance decides the supportability degree of the one affected by shame. The series grand-petit-moindre-zeste and poids-léger - meant to support the physical character of a trauma-have been diluted using similar series, where some of the terms were chosen for their poetizing valences ${ }^{7}$. For instance, un zeste de honte, where zeste continues the series of "quantifiable" properties-according to the very title of the chapter-is rendered by o farimă (it can be quantified, but it is a rare and rather poetical term). Periphrasis and the preference for more poetic synonyms thus become the tutelary figures, the norm of the translation, which is quite the opposite of the project of a specialized text in general and of this text in particular.

Un souvenir d'enfance 8 // $O$ amintire din copilărie

Alain... s'est tué... sans jamais avoir éprouvé le moindre sentiment de honte simplement la petite honte

\section{Le détracteur intime // Detractorul intim}

la honte est plus légère

le poids de la honte

c'est ma honte, ma grande honte
Alain... s-a sinucis... fără să fi încercat

vreodată cel mai mărunt sentiment

de ruşine

pur și simplu e în discuţie doar

mărunta rușine

ruşinea este mai suportabilă

apăsarea rușinii

e rușinea mea, marea mea rușine

o uşoară senzație de rușine

La bonte et son contraire // Ruşinea și opusul ei une petite honte

La honte peut durer deux heures ou vingt ans // Ruşinea poate dura două ore sau două decenii

les petites hontes de la vie quotidienne măruntele rușini ale vieții cotidiene un zeste de honte

o fărîmă de rușine

\footnotetext{
${ }^{7}$ It is also worth mentioning the emergence of the diminutive ruşinică in the recent past, which humorists used at a certain point to mock the various deviations of the politicians, but it does not seem to have become a common word.

${ }^{8}$ For the fluidity of reading and taking into account the small size of the subchapters, I preferred to group the examples within the tables by subchapters and to provide the titles of the latter.
} 
Bonheur et pulsions. Honte et morale // Fericire și pulsiuni. Rușine și morală

une petite honte

une grande honte un uşor sentiment de rușine

o rușine amplificată

\section{Translation of concepts}

The text is situated halfway between a specialized treatise and an essay. At the same time, the text is not a popularization book, insofar as the author is also a narrator, considering that sometimes the "voice" of the psychiatrist becomes the voice of the "patient", (in the first person).

Many have considered the very decision of translating the discourse of humanities a "profanation" of the intentionality-transmitting universal contents—specific to such a text. Jean-René Ladmiral (Ladmiral, 1998, p. 977-994) assimilated this decision to a derogation of Reason itself. Using operations that dissociate "the conceptual signifieds of philosophy [...] from the signifiers [...] of the original language, to later ensure their «reincarnation» in other signifiers, in foreign signifiers, of the language of arrival or «target language» of the translated text" (Ladmiral, 1989, p. 6) is a veritable "scandal" for the French translation studies specialist and translator (Ladmiral, 1989, p. 988) ${ }^{9}$. In his opinion, a philosophical text has the purpose of unravelling a universalizing Reason without knowing how to avoid not only "the historical and cultural sense of identity of national traditions," but also the "linguistic accidents, justly called «idiomatic», of natural languages." Hence, more than in any other type of text, the translation reveals a terrible tension: "the rational transparency of conceptual signifieds that represents the aim of the philosophical discourse [...] is shadowed by the contingent «impurities» of the linguistic signifier" (Ladmiral, 1998, p. 983). This is precisely why Ladmiral believes that any classical oppositions (technical translation versus literary translation) and more complex typologies (i.e. the one proposed by Katharina Reiss) have no genuine methodological utility. Therefore, besides pragmatic translations ("applicable" to referent-focused texts) and literary translations (of texts where the expressive function of language dominates), it would be useful to add another category of texts, the one of humanities discourse, whose referent is its own signified.

Hence, the philosophical text appears like a stratified structure (which stimulates the polemics regarding the translation manners- unified or not-of the two levels, of specialized language and of narration). Whatever the case, the translator has the task of differentiating between the language of the text and the word of the author, namely the system of indicators leaving the print of a particular subjectivity upon the text (Ladmiral, 1994, p. 223).

\section{Reticence about neologizing: the impossible nominalization}

The nominalization of the adjective honteux into le honteux involves-in not only French, but also in Romanian, German and Spanish—a neologizing effort; the nominalization of the adjective is probably equally acceptable in the four languages. It is clear that, once the translators had the courage of imposing it, (thus preserving strictly the coherence of the terminology within the original text) the terms were accepted as such, while both der Beschämte (Gehring, 2011) and el avergonzado (Almonte, 2011, p. 387388; Tristán, 2011) have been used by the authors of reviews for this book.

In Romanian, however, the translator's reticence prevented the chance of enriching terminologies. I have noted the translator's continual effort (even hassle, I would call it) of translating the category of "those who suffer from shame" in diverse ways: he thus seems to compensate his own reticence (to neologize the adjective ruşinos by nominalizing it) by a whole array of periphrases. Nonetheless, the purpose of the

\footnotetext{
${ }^{9}$ Paul Ricœur also approached this scandal, when he invoked the indeterminacy defined by Quine as specific to all translations, but which becomes especially obvious in philosophical translations (endowed with a rigours semantic framework), where it acquires the form of a paradox (Ricœur, 2005, p. 70).
} 
source text is not to prove some lexical "artistry" or to compensate the fear of repetitions, but to construct and to define - like any other specialized text - a well-established grid of concepts, among which a central role is occupied precisely by the naming of the person affected by the trauma of shame.

Romanian could have provided two nominalization possibilities, both with far-reaching semantic spheres, oscillating between timidity, shyness (related to pudoare), and shame "per se": on the one hand, ruşinosul, but which appears to be a "weak" term insofar as it rather connotes sfiala, timiditatea. On the other hand, ruşinatul, by derivation using the affix - at, which references the same nuances of meaning but also "copleșit de rușine" [overwhelmed by shame]. The decision is definitely a difficult one: translators generally avoid neologizing, because it exposes them to various critiques, but in this case, it would have been essential for constructing the terminological grid. Moreover, dispersing it into numerous periphrases did not do any service to the translation. The term of choice should not have suggested that much shyness, reserve, because the topic of the book regards the cases of serious traumas of all types: uproot, rape, poverty, but also excessive enrichment, expulsion from a group, surviving concentration camps, etc. From this perspective, the best choice would not be the noun ruşinosul (that also means shy, timid; these character traits have nothing to do with the cases approached in the book). The best term would be the noun rusinatul: the one who is traumatized and is most of the times aware of his trauma when he confronts the others. The filthy child who realizes suddenly his own state when a woman who wants to provide him shelter for a few days gives him a terrified look, and who thus becomes ruşinat not of the way he looks (as rendered in the Romanian version), but of his own image reflected in the look of the other and which he perceives for the first time.

\section{La manière d'aimer est un mode de socialisation // Felul în care iubim este o modalitate de socializare l'enfant eut honte de ce qu'il était sous le regard de cette dame \\ copilului i se făcu rușine de felul cum arăta}

In only one occurrence, at the beginning of the book, the translator nominalizes it—noi, ruşinoşii (p. 12)— but throughout the rest, he uses all sorts of periphrases. Hence, this single occurrence seems rather a "negligence" that he subsequently corrected in the rest of the text. The same sentence features the antonym of les honteux, l'éhonté, and the translator misses the grid again, though he could have used the Romanian derivative word, namely neruşinat. However, he misinterprets and chooses the term neobräzat, which refers to obrăznicie, impertinență, necuviințăa, when the French word simply meant lipsa ruşinii [lack of shame] of the person who does not feel guilty for having divorced from his wife who later committed suicide. Undoubtedly, neobrăzarea is not a flaw of the person, in this case, but the incapability of feeling shame. If I am not mistaken, this is the only occurrence of ébonté: the author seems to choose an excess transparency in his conceptual grid; hence, towards the end of the book, he entitles one subchapter Les sans-honte (p. 236-243). He thus creates a compound noun based on the adverbial phrase to designate the category of those who do not feel, qui n'éprouvent pas, p. 219 (not care nu arată [who do not show it], as featured in Romanian; the issue is not whether they show it or not) "nici ruşine, nici mîndrie" [neither shame nor pride] (p. 219). Cei fără ruşine is the Romanian version: I wonder whether it maybe would have been better to use the dash for a term such as cei-färă-de-rusine, which may have represented a potential concept.

By dispersing it into numerous periphrases, the Romanian version fails to reconstruct the basic terminological grid, centred on shame - the one who suffers from this trauma. The periphrases per se could be accepted at a pinch, as in the aforementioned example, but only if it features a single formula, not a whole array of synonyms that many times add subjective, contradictory nuances for their type of context. He could have used the neutral suferindul de ruşine if he lacked the courage to use ruşinatul, but no other variation is acceptable. He would have thus avoided impressionist structures such as cel apăsat de ruşine, omulplin de ruşine, omul tulburat de ruşine, not to mention the colloquial and defiant crede că are probleme cu ruşinea. As for the commonly used formula omul (burdened by, troubled by, who suffers from, etc. rușine), it is at least sloppy: whereas it is a collective noun, this Romanian noun does not necessarily 
include both genders.

Introduction

Le honteux omul căruia îi este rușine

Un souvenir d'enfance // $O$ amintire din copilärie nous les honteux noi, rușinoșii

Sortir de la honte comme on sort d’un terrier // Să ieşim din ruşine ca dintr-o vizuină

le honteux omul care se rușinează

le honteux préfère cel apăsat de rușine preferă

Le détracteur intime // Detractorul intim

un honteux un individ, suferind de rușine

le honteux omul căruia îi este ruşine

le honteux omul care suferă de rușine

le honteux individul bolnav de rușine

le honteux cel apăsat de ruşine

le honteux subiectul suferind de rușine

un honteux celui căruia îi este rușine

le honteux cel apăsat de ruşine

des honteux oameni plini de rușine

Transparence du honteux // Transparența celui care suferă de ruşine

le honteux omul care suferă de rușine

le honteux préfere individul plin de rușine

le honteux cel suferind de rușine

La réussite, un masque de la honte // Reuşita, o mască a ruşinii

le honteux individul care suferă de rușine

Leurre de vérité // Momeala adevărului

le honteux individul care suferă de rușine

le honteux cel bolnav de rușine

le honteux omul tulburat de ruşine

le honteux omul apăsat de rușine

Plus le malheur est grand, plus la victoire est glorieuse // Cu cît nefericirea este mai mare, cu-atît victoria este mai glorioasă

chez les honteux la cei apăsaţi de rușine

certains honteux unii [...] cărora le este rușine

Le „je” n'existe quiauprès d'un autre // „Eul” nu există decît în raport cu un altul

le honteux cel care suferă de rușine

le honteux cel apăsat de acest sentiment

Un monde où tout fait honte // O lume în care orice stîrnește ruşinea

le honteux

individul plin de rușine

le honteux

oamenii care suferă de rușine

Honte ou culpabilité? // Rușine sau vinovăție?

un honteux

cineva suferind de rușine

le honteux

individul care suferă de ruşine 
Lilliput, star de la honte // Liliputanul, vedeta ruşinii
le honteux
celui suferind de rușine
le honteux
cel afectat de rușine

Tout le monde participe à la honte // Toată lumea ia parte la ruşine
le honteux
indivizii suferind de rușine
le honteux
cel apăsat de rușine

On ne s'attache pas au plus gentil ou au plus diplômé, on s'attache à ceux qui nous sécurisent // Nu ne ataşăm de cel mai amabil sau mai diplomat, ne ataşăm de cei care ne securizează

le honteux

cel rușinos

le petit honteux

micuțul suferind de rușine

le petit honteux

copilul afectat de rușine

Effet désocialisant de la souffrance morale // Efectul desocializant al suferinței morale

du honteux

subiectului apăsat de rușine

le honteux

cel suferind de rușine

Qui suis-je pour l'autre? // Cine sint eu pentru celălalt?
le honteux
cel apăsat de rușine
le honteux
cel suferind de rușine

Nègres, zoos et hôpitaux psychiatriques // Negri, grădini zoologice și spitale psibiatrice

le honteux

individul apăsat de rușine

Le couple, atome de société // Cuplul, atomul societății

le honteux se persuade

il pense qu'il est honteux

que le honteux donne à celui qui le re-

garde

Le pouvoir des chaussettes // Puterea ciorapilor

le honteux

le honteux cel care suferă de ruşine se va convinge crede că are probleme cu rușinea pe care individul suferind de rușine o dăruiește celui care îl privește

individul apăsat de rușine

omul ruşinat

Dissipated as such in the translation, the semantic series honte - bonteux - le bonteux - éhonté that actually illustrates a trauma that is always the same and the one traumatized (translated using more or less periphrastic formulas) undermines the basic semantic network. This network seems to fumble constantly in search for its own name: however, this is not the structure of the original text. In fact, the original text does not suggest terminological uncertainty and it does not aim to describe the manner of elaborating certain concepts. In the translation of literary texts, this translational technique may end up destroying the symbolism of the source text, (which becomes invisible, masked by lexical dispersion) or at least it illustrates the use of aesthetics foreign to the source text (Berman, 1999, p. 391, 393). When the translated text is a specialized one, however, the reader will not admire the lexical-creative artistry of the translator; on the contrary, the reader has the feeling of participating in the failure of a researcher incapable of supporting his discourse on a solid conceptual framework, fumbling through peri- and paraphrases.

[Translated by Alina Piftor] 


\section{Bibliography}

Almonte, C. (2011). Comentario de libros: Morirse de vergüenza, in "Psiquiatría universitaria", p. 387-388, [online].

Berman, A. (1999). La traduction et la lettre ou l'auberge du lointain, Seuil, Paris.

Bourguignon, A., Cotet, P., Laplanche, J. \& Robert, F. (1989). Traduire Freud, PUF Paris.

Cassin, B. (éd.) (2004). Vocabulaire européen des philosophies. Dictionnaire des intraduisibles, Éditions du Seuil/Le Robert, Paris.

Cleynen-Serghiev, E. (2003). „Les Belles Infidèles” en Roumanie. Les traductions des auvres françaises durant l'entre-deux-guerres (1919-1939), Presses Universitaires de Valenciennes, Valenciennes.

Cornea, P. (1972). Ce ne dezvăluie traducerile de la sfirşitul sec. al XVIII-lea și începutul secolului al XIXlea, in Originile romantismului românesc, Minerva, București.

Craşoveanu, D. (2002). Categorii sintactice necircumstanțiale, Editura Mirton, Timișoara.

Cyrulnik, B. (2010a). Mourir de dire. La Honte, Odile Jacob, Paris.

Cyrulnik, B. (2010b). J’ai connu la honte, interviu de Émilie Lanez, in “Le Point”, Sept. 2, [online].

Cyrulnik, B. (2011a). Scham. Im Bann des Schweigens - Wenn die Seelevergiftet, transl. Maria Buchwald and Andrea Alvermann, Präsenz Kunst und Buch Verlag, Hünfelden.

Cyrulnik, B. (2011b). Morirse de vergüenza. El miedo a la mirada del otro, transl. Maria Pons Irazazábal, Editura Debate, Barcelona.

Cyrulnik, B. (2012). Mai bine mor decât să spun. Ruşinea, transl. Valentin Protopopescu, Editura Trei, București.

Cyrulnik, B. (2013). J'ai surmonté la honte, ce poison de l'âme, interview by Isabelle Vial, in "Pèlerin", no. 6673, July 16, [online].

Eliade, P. (2000). Influența franceză asupra spiritului public în România. Originile, transl. Aurora Dumitrașcu, Humanitas, București.

Freud, S. (1900). Die Traumdeutung, în Studienausgabe, S. Fischer Verlag, Frankfurt am Main.

Freud, S. (1909). Analyse der Phobie eines fünfjährigen Knaben, in Studeineausgabe, vol. 8, S. Fischer Verlag, Frankfurt am Main. Freud, S. (2010a). Opere esențiale. Interpretarea viselor, vol. 2, transl. Roxana Melnicu, Editura Trei, București.

Freud, S. (2010b). Micul Hans. Analiza fobiei unui băiețel de cinci ani, in Opere esențiale. Nevroza la copil, vol. 8, transl. Rodica Matei și Ruxandra Hosu, Editura Trei, București.

Gehring, P. (2011). Eine Art innere Gefangenschaft, in "Frankfurter Allgemeine Zeitung”, Oct. 5, [online].

Graur, Al. (1973). Gramatica azi, Editura Academiei, București.

Ionescu, G. (1981). Cîteva repere, in Orizontul traducerii, Univers, București.

Janin, Cl. (2003). Pour une théorie psychanalytique de la honte (honte originaire, honte des origines, origines de la honte), in "Revue française de psychanalyse”, vol. 67, no. 5, p. 1657-1742, Crossref.

Kinston, W. (1983). A theoretical context of shame, in "International Journal of Psycho-Analysis", no. 64, p. $213-226$.

Ladmiral, J.-R. (1989). Pour une philosophie de la traduction, in "Revue de métaphysique et de morale. La traduction philosophique", no. 1, Éditions Armand Colin, Paris.

Ladmiral, J.-R. (1994). Traduire: théorèmes pour la traduction, Éditions Gallimard, Paris.

Ladmiral, J.-R. (1998). Principes philosophiques de la traduction, in Encyclopédie philosophique universelle, ed. André Jacob, vol. IV, PUF, Paris.

Popovici, D. (1977). Studii literare. III, Dacia, Cluj-Napoca.

Reiss, K. (2002). La critique des traductions, ses possibilités et ses limites, transl. Catherine Boquet, Artois Presses Université.

Ricœur, P. (2005). Despre traducere, transl. and introductory study by Magda Jeanrenaud, afterword by Domenico Jervolino, Polirom, Iași.

Rosenblum, R. (2000). Peut-on mourir de dire? Sarah Kofman, Primo Levi, in "Revue française de psychanalyse", LXIV, no. 64, Crossref.

Semprun, J. (1994). L'écriture ou la vie, Gallimard, Paris.

Tristán, R.M. (2011). Claves para nómorirse de vergüenza, in “El Mundo”, Nov. 13, [online]. 